http://dx.doi.org/10.11646/phytotaxa.156.2.2

\title{
Utricularia julianae (Lentibulariaceae), a new species from the savannas of the Oyapock River, French Guiana
}

\author{
PIERO G. DELPRETE ${ }^{1 *}$ \\ ${ }^{1}$ Herbier de Guyane, Institut de Recherche pour le Développement (IRD), UMR AMAP, Boite Postale 165, 97323 Cayenne Cedex, \\ French Guiana, France; e-mail: piero.delprete@ird.fr \\ *Author for correspondence
}

\begin{abstract}
Utricularia julianae, a new species from the savannas near the Oyapock River, French Guiana, is here described and illustrated. The new species is most similar to U. tenuissima, from which it can be easily distinguished by the leaves and stolons apparently lacking (vs. leaves few and on the stolons, the stolons few or lacking, in U. tenuissima), traps ellipsoid, $0.3 \mathrm{~mm}$ long, with 4-5 capilliform appendages (vs. ovoid, 0.3-0.8 mm long, with 1 dorsal and 2 ventral slender appendages), corolla upper lip limb deeply bilobed (vs. broadly ovate to round), spur saccate, perpendicular to the lower lip (vs. spur narrowly cylindrical, parallel to the lower lip), among other characters. In addition, the capsules of $U$. julianae and $U$. tenuissima are unique within the genus, by being very narrowly ovoid, dehiscing by a single longitudinal slit, and with a placenta projecting outside the dehisced capsule. On the basis of their numerous morphological similarities and their peculiar capsule shape and dehiscence, the new species is tentatively placed within sect. Martinia, which P. Taylor described to accommodate U. tenuissima.
\end{abstract}

Key words: Savane Jardin Caché, Section Martinia, critically endangered species, taxonomy

\section{Introduction}

The genus Utricularia Linnaeus (1753: 18) comprises ca. 220 species worldwide (Müller et al. 2006). According to the most recent checklist produced for the Guiana Shield (Taylor 2007), 34 species of Utricularia are present in the Guianas (Guyana, Suriname and French Guiana). The classic treatment for identifying species of this genus is the worldwide monograph published by Taylor (1989), who dedicated most of his life towards this endeavor. Additional regional references (i.e., Guayana Highlands, Venezuelan Guayana) for identification of Utricularia species were also provided by the same author (Taylor 1967, 1999).

Recent molecular phylogenies (Müller et al. 2005; Müller \& Borsh, 2005) confirmed that the three genera traditionally recognized in the family Lentibulariaceae, namely Pinguicula Linnaeus (1753: 17), Genlisea SaintHilaire (1833: 428) and Utricularia, are monophyletic. Also, Taylor (1989) recognized two subgenera in Utricularia: subgenus Utricularia, with two calyx lobes, and subgenus Polypompholyx (Lehmann 1844: 109) Taylor (1986: 1), with four calyx lobes; however this subdivision is not supported by molecular phylogenies (Müller \& Borsh, 2005).

The genus most closely related to Utricularia is Genlisea, which is characterized by its "Y-shaped, twisted, subterrestrial eel traps used to attract and trap protozoa" (Barthlott et al. 1998; Müller et al. 2005), whereas Utricularia "exhibits the most complex trapping device, among the most complicated leaf modifications known in the plant kingdom. The bladder traps of Utricularia are either submerged or subterrestrial and work by means of low pressure" (Müller et al. 2005). Additionally, the flowers of Utricularia are easily distinguished from those of Genlisea by the 2- or 4-lobed calyx (vs. 5-lobed in Genlisea) (Müller et al. 2006, Taylor 1999).

During a recent expedition to the savannas near the Oyapock River, French Guiana, a small, white-flowered species of Utricularia was discovered. Although I performed considerable field work in the coastal savannas of French Guiana over the last four years, this species was never seen before. Additionally, the Savane Jardin Caché, 
where this plant was collected, is poorly known, mostly because it is difficult to reach. The first collecting expedition to this savanna was made by canoe, on 17 July 2010, going ca. $5 \mathrm{~km}$ downstream from Saint-George de l'Oyapock on the Oyapock River, and then walking $4 \mathrm{~km}$ through inundated lowland forest. A second expedition was made by helicopter, on 7 June 2013. It was during the second expedition that the here described new species of Utricularia was discovered. The name Savane "Jardin Caché" (meaning "hidden garden" due to the diversity and abundance of flowers present, and the high density and diversity of bees visiting the flowers) was given by the participating members of the first expedition (Ruth Bone, Gina Lolli, Helene Richard, and myself) because up to that moment this locality was still unnamed; so, this is also the first publication wherein this savanna is officially named. Due to its peculiar nature (black and white sand of granitic origin, located near the Oyapock River) and its unique floristic composition, efforts will be undertaken by the organization Conservatoire du Littoral to acquire this site and to place it under the status of protected area.

\section{Material and Methods}

This study was based on field observations and examinations of herbarium specimens collected at the Savane Jardin Caché, French Guiana (France). Herbarium specimens were deposited at the CAY, K and US herbaria. A few specimens preserved in $70 \%$ ethanol are also deposited at CAY, to facilitate the study of vegetative and reproductive parts of this minute species. Dried and pickled specimens were examined using a dissecting microscope. Conservation status was assessed applying the IUCN Red list Categories and Criteria version 3.1 (IUCN 2001).

\section{Description}

Utricularia julianae Delprete, sp. nov. (Fig. 1)

Type:-FRENCH GUIANA. Commune de Regina: Savane Jardin Caché (a few km air distance from the Oyapock River), savanna surrounded by primary forest, open field dominated by Poaceae, Cyperaceae and with frequent patches of Eriocaulaceae, soil with coarse, salt-and-pepper sand (black and white grains, of granitic origin), $04^{\circ} 02^{\prime} 52^{\prime} \mathrm{N}$, 51 43 '47'W, 10 m, 7 June 2013, fl. and fr., P.G. Delprete 12160 (holotype, CAY!; isotypes K!, US!).

Delicate herb, 3.5-5.5 cm tall, single-stemmed, annual, terrestrial. Stem filiform. Rhizoids few (commonly 3-5), filiform, ca. 3.5-5.5 mm long, ca. $0.1 \mathrm{~mm}$ thick, without papillose branchlets. Stolons absent. Leaves apparently absent (absent at the time of collection). Traps few, present on the rhizoids, ellipsoid, $0.3 \times 0.2 \mathrm{~mm}$, stalked, laterally attached, the mouth lateral, with 4-5 capilliform appendages evenly distributed along the edge of the mouth trap. Internal trap glands not studied. Inflorescence erect, solitary, simple; peduncle filiform, terete, glabrous, $0.2 \mathrm{~mm}$ thick. Scales few, along the stem, narrowly ovate, $0.3-0.5 \mathrm{~mm}$ long, similar to the bracts. Bracts basifixed, narrowly ovate, $0.3-0.5 \mathrm{~mm}$ long. Bracteoles narrowly ovate, $0.3 \mathrm{~mm}$ long. Raceme with $1-2(-3)$ flowers, with internodes $6-9 \mathrm{~mm}$ long; pedicels erect, filiform, terete, $0.3-0.5 \mathrm{~mm}$ long. Calyx lobes subequal, membranous, glabrous, with a single central vein, upper lobe ovate, $0.8-0.9 \times 0.5-0.6 \mathrm{~mm}$, acute or tridentate at apex, lower lobe narrowly ovate, $0.8-0.9 \times 0.4 \mathrm{~mm}$, retuse at apex. Corolla pure white (white to pale purplishwhite when dry), with a yellow blotch at the base of the lower lip; upper lip 2-2.2 $\mathrm{mm}$ long, deeply bilobed, the lobes oblong, 1-1.2 mm long, the basal sac with a distinct, glabrous, raised marginal rim; lower lip limb 2.9-3.2 $\mathrm{mm}$ long, broadly ovate, with a small, basal swelling, obtuse to truncate at apex, the margin shallowly undulate to obviously crenulate; palate conspicuously ciliate with moniliform hairs; spur saccate (slightly wider near the apex), subacute at apex, straight, shorter than and perpendicular to the lower lip. Filaments slightly curved, $0.3 \mathrm{~mm}$ long, the anther thecae ca. $2.5 \mathrm{~mm}$ long, \pm confluent. Ovary ovoid; style short, relatively narrow; stigma lips unequal, ovate, acute at apex, narrower than the ovary. Capsule very narrowly oblong-ovoid, $1.5-1.7 \mathrm{~mm}$ long, $0.4-0.5 \mathrm{~mm}$ wide, the wall uniformly membranous, dehiscing by a single, longitudinal, ventral slit, the placenta shortly stipitate, narrowly cylindrical, barely protruding outside the dehisced capsule. Seeds ca. $0.10 \mathrm{~mm}$ long.

Etymology:-The specific epithet honors my wife, Juliana Costa da Silva, who has accompanied me for many years during field and herbarium work in South America. The day of the helicopter expedition, when this plant was 
collected, she (at that time wife-to-be) remained at home, anxiously waiting for my return, because she believes that helicopter flights are dangerous. For these reasons, this rare, minute and precious species is dedicated to her.
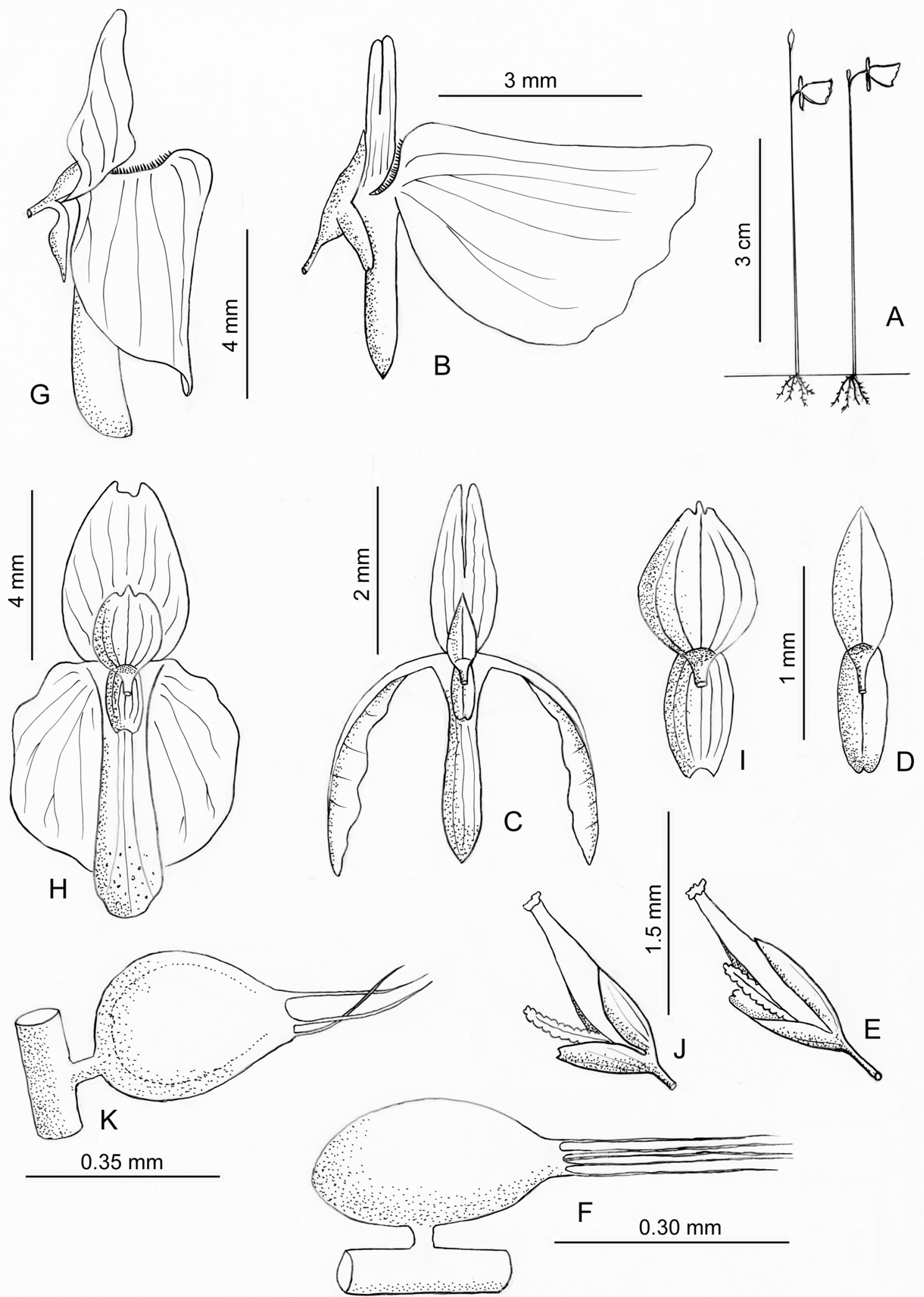

FIGURE 1. A-F. Utricularia julianae. A. Habit. B. Flower, lateral view. C. Flower, posterior view. D. Calyx, posterior view. E. Dehisced capsule, with barely protruding placenta. F. Trap, lateral view. G-K. Utricularia tenuissima. G. Flower, lateral view. H. Flower, posterior view. I. Calyx, posterior view. J. Dehisced capsule, with protruding placenta. K. Trap, lateral view. A-F: drawn from Delprete 12160; G-K: redrawn from Taylor, 1989, fig. 67. Illustration by Piero G. Delprete. 
Distribution, Habitat and Ecology:- The only collection known of this species is from Savane Jardin Caché (a few km by air from the Oyapock River), an open field savanna dominated by Poaceae, Cyperaceae, with frequent patches of Eriocaulaceae, and surrounded by primary forest. The observed small population, consisting of no more than 50 individuals, was growing in the semi-shade of the surrounding forest. The soil of the savanna is composed of coarse, salt-and-pepper sand (black and white grains) of granitic origin. The savanna is subjected to the two main seasons present in French Guiana: the dry season (from August to November) and the rainy season (from December to July). At the time of the collection, it was towards the end of the rainy season, when the soil of the savanna was soaked in water, but not inundated. Considering the small size of the individuals and their environmental condition, this species is doubtless ephemeral, and with a life span of just a few weeks. The single flowering collection was made in June.

Suggested conservation status:- - This species is up to now only known from a single population of no more than 50 individuals, indicating that it is very rare. After four years of intense collecting in the coastal savannas of French Guiana, this is the first time that it has been seen; however, there is a small probability that it might have been overlooked, due to the small size of the individuals and its ephemeral life span. Therefore, taking into account the small area of occupancy and the small population observed this species should be treated as "Critically Endangered" (CR) following IUCN D criterium (IUCN 2001).

Taxonomic relationships:-According to the dichotomous keys and descriptions provided by Taylor (1967: 207-209, 214; 1989: 67-73, 261), the most similar species to Utricularia julianae is U. tenuissima Tutin (1934: 334). However, it can be distinguished from the latter (as described and illustrated by Taylor 1989: 261, fig. 67, and by Fernández-Pérez 1964: 52, fig. 16) by the leaves and stolons apparently lacking (vs. stolons few or absent, leaves few, on the stolons in U. tenuissima), traps ellipsoid, $0.3 \mathrm{~mm}$ long, laterally attached, with 4-5 capilliform appendages (vs. ovoid, $0.3-0.8 \mathrm{~mm}$ long, basally attached, with 1 dorsal and 2 ventral, slender appendages), calyx lobes 1-veined (vs. 5-veined), calyx lower lobe retuse at apex (vs. bidentate at apex), corolla upper lip limb deeply bilobed, with lobes oblong, 1-1.2 mm long (vs. broadly ovate to round), corolla lower lip limb broadly ovate, with shallowly undulate to obviously crenulate margin (vs. round, with entire or minutely crenulate margin), spur narrowly cylindrical, parallel to the lower lip (vs. saccate, perpendicular to the lower lip), and the stigmatic branches unequal, ovate, acute at apex (vs. subequal, round, obtuse at apex). A comparative summary of the characters that differentiate these two taxa is presented in Table 1.

TABLE 1. Comparative table of morphological characters distinguishing Utricularia tenuissima (sensu Taylor 1989) from U. julianae.

\begin{tabular}{|c|c|c|}
\hline & Utricularia tenuissima & Utricularia julianae \\
\hline Stolons & Few or absent & Absent \\
\hline Leaves & Few on the stolons & Absent \\
\hline Traps number and position & $\begin{array}{l}\text { Numerous, on leaves, stolon branches and } \\
\text { rhizoids }\end{array}$ & Few, on rhizoids \\
\hline Trap morphology & $\begin{array}{l}\text { Ovoid, } 0.3-0.8 \mathrm{~mm} \text { long, basally attached, } \\
\text { with } 1 \text { dorsal and } 2 \text { ventral slender } \\
\text { appendages }\end{array}$ & $\begin{array}{l}\text { Ellipsoid, } 0.3 \mathrm{~mm} \text { long, laterally attached, with } 4-5 \\
\text { capilliform appendages }\end{array}$ \\
\hline Calyx lobes & $\begin{array}{l}\text { 5-veined } \\
\text { Upper lobe broadly ovate } \\
\text { Lower lobe bidentate at apex }\end{array}$ & $\begin{array}{l}\text { 1-veined } \\
\text { Upper lobe ovate } \\
\text { Lower lobe retuse at apex }\end{array}$ \\
\hline Corolla color & Violet, mauve or white & $\begin{array}{l}\text { Pure white when fresh (white to pale purplish-white } \\
\text { when dry) }\end{array}$ \\
\hline Corolla upper lip limb & Broadly ovate to round (apex shortly bilobed) & Deeply bilobed, the lobes oblong, $1-1.2 \mathrm{~mm}$ long \\
\hline Corolla lower lip limb & Round, margin entire or minutely crenulate & $\begin{array}{l}\text { Broadly ovate, margin shallowly undulate to } \\
\text { obviously crenulate }\end{array}$ \\
\hline Spur & Narrowly cylindrical, parallel to the lower lip & Saccate, perpendicular to the lower lip \\
\hline Stigmatic branches & Subequal, round, obtuse at apex & Unequal, ovate, acute at apex \\
\hline
\end{tabular}


It is worth noting that as concerns $U$. tenuissima there is a certain discrepancy between the description and illustration provided by Taylor and the type specimens. In fact, Taylor (1989: 261, fig. 67) described and illustrated U. tenuissima as having the spur parallel to the lower corolla limb lip, a feature noted by Tutin when he collected the type material, whereas the type specimens (Tutin 644, BM!, K!, L!, NY!) have the spur perpendicular to the lower limb lip.

The capsules of Utricularia tenuissima and $U$. julianae are quite similar by being very narrowly ovoid, dehiscing by a single longitudinal slit, and by having a shortly stipitate placenta that is projected outside the dehisced capsule. On the basis of these numerous morphological similarities, and their capsule shape and dehiscence unique within the genus, the new species is provisionally placed in sect. Martinia Taylor (1986: 7), which was described to accommodate $U$. tenuissima. Further phylogenetic analyses will eventually test this placement and the monophyly of this section.

\section{Acknowledgments}

I would like to thank Olivier Tostain and Guillaume Leotard, for accompanying me during the helicopter expedition of 7 June 2013, on the savannas and inselbergs near the Oyapock River, French Guiana. Funds for the expedition were provided by the organization Conservatoire du Littoral.

\section{References}

Barthlott, W., Porembski, S., Fisher, E. \& Gemmel, B. (1998) First protozoa-trapping plant found. Nature 392: 447. http://dx.doi.org/10.1038/33037

Fernárdez-Pérez, A. (1964) Plantas insectivoras, I: Lentibulariaceae de Colombia y Peru. Caldasia 9(41): 5-84.

IUCN (2001) IUCN Red List Categories: Version 3.1. IUCN Species Survival Commission, IUCN, Gland, Switzerland and Cambridge, U.K., ii +30 pp.

Lehmann, J.G.C. (1844) Polypompholyx. Botanische Zeitung (Berlin) 2: 109.

Linnaeus, C. (1753) Species Plantarum 1. Impensis Laurentii Salvii, Stokholm, 560 pp.

Müller, K.F. \& Borsch, T. (2005) Phylogenetics of Utricularia (Lentibulariaceae) and molecular evolution of the trnK intron in a lineage with high substituion rates. Plant Systematics and Evolution 250: 39-67. http://dx.doi.org/10.1007/s00606-004-0224-1

Müller, K.F., Borsch, T., Legendre, L., Porembski, S. \& Barthlott, W. (2006) Recent progress in understanding the evolution of carnivorous Lentibulariaceae (Lamiales). Plant Biology 8: 748-757. http://dx.doi.org/10.1055/s-2006-924706

Saint-Hilaire, A. (1833) Voyage dans le District des Diamans, volume 2. Librarie-Gide, Paris, 456 pp.

Taylor, P. (1967) Lentibulariaceae. In: Maguire, B. and Collaborators, Botany of the Guayana Highlands — Part VII. Memoirs of the New York Botanical Garden 17: 201-228.

Taylor, P. (1986) New taxa in Utricularia (Lentibulariaceae). Kew Bulletin 41: 1-18. http://dx.doi.org/10.2307/4103020

Taylor, P. (1989) The genus Utricularia - a taxonomic monograph. Kew Bulletin Addition Series XIV. London: Royal Botanic Garden, Kew, $724 \mathrm{pp}$.

Taylor, P. (1999) Lentibulariaceae. In: Steyermark, J.A., Berry, P.E., Yatskievych \& Holst, B.K., Flora of the Venezuelan Guayana, Vol. 5. Missouri Botanical Garden Press, St. Louis, pp. 782-803.

Taylor, P. (2007) Lentibulariaceae. In: Funk, V., Hollowell, T., Berry, P., Kelloff, C. \& Alexander, S.N. (eds.) Checklist of the plants of the Guiana Shield (Venezuela: Amazonas, Bolivar, Delta Amacuro; Guyana, Surinam, French Guiana). Contributions from the United States National Herbarium 55: 376-379.

Tutin, T.G. (1934) Utricularia tenuissima. New species from British Guiana, Cambridge University Expedition, 1933. Journal of Botany, British and Foreign 72(864): 334-335, f. 7. 